\title{
OBSERVATIONS ON THE NATURE OF THE SERUM PROTEINS IN NEPHROSIS
}

\author{
By E. GOETTSCH AND E. B. REEVES \\ (From the Department of Diseases of Children, College of Physicians and Surgeons, Columbia \\ University, and the Babies Hospital, New York City)
}

(Received for publication November 21, 1935)

The nature of the serum and urinary proteins in kidney diseases has led to numerous investigations. Leiter (1) suggested that the pathogenesis of nephrosis " rests upon this one question -are the urinary and plasma proteins qualitatively or biologically different from the normal?" Widdowson (2) in an attempt to determine whether protein is altered during passage through the kidney estimated the Van Slyke distribution fractions, racemization curves, osmotic pressures, and specific refractions of serum and urinary proteins from nephritic and nephrotic patients. She found that both the albumin and globulin of urine were identical with the corresponding fractions in serum, which agrees with the earlier studies of Hewitt (3), and of Cavett and Gibson (4); and that the serum and urinary proteins isolated from nephritic patients were identical with normal serum proteins. In one patient with nephrosis, however, slight differences in chemical structure were present although the physical measurements were the same. Since the chemical differences were represented by variations in the ammonia nitrogen fraction of 1.0 per cent for albumin and 2.0 per cent for globulin, and by differences in the basic nitrogen fractions of 2.0 per cent, and since only one patient was studied, little significance was attached to the results. She concluded that serum albumin and globulin were not altered by passage through the kidney in nephritis and nephrosis.

Early immunological studies were likewise interpreted to indicate that serum and urinary proteins were identical in composition. Mertens (5) prepared an antiserum to protein isolated from human urine and obtained a precipitate when this antiserum was mixed with human serum, while no precipitate was formed with rabbit serum or with rabbit urine containing protein. Erben (6) fractionated urinary protein and made an antiserum with the globulin fraction, which also threw down a precipitate with normal serum. means of precipitin and other serological studies, F. Müller (7) was unable to demonstrate the presence of a foreign protein in the urine of nephrotic patients, and concluded that the proteins of urine and serum were identical in composition. Recent immunological studies have led to the opposite conclusion. Welker, Thomas and coworkers (8) presented evidence on the basis of precipitin studies, that the urine of nephrotic patients contains a relatively non-toxic peptone combined with or absorbed by normal serum proteins, as well as a highly toxic blood protein in an extremely fine state of dispersion. During the early stages of experimental nephritis in dogs urinary protein was found to consist largely of tissue proteins, especially liver, while in the later stages it was composed mostly of serum proteins. These workers proposed the theory that albuminuria was a highly protective mechanism in detoxication of poisonous tissue proteoses. Cowie and Magee (9) recently were unable to obtain confirmation of tissue specificity. They produced antisera in rabbits against liver, spleen, kidney, and serum from human cadavers and found that each of these antisera was precipitated equally well by all of the antigens. In none of the above studies were the precipitin tests done quantitatively.

The present study developed in the course of an investigation of the albumin: globulin ratios of serum, urine, and transudates in nephrosis and nephritis by means of the quantitative precipitin method (10). By this method transudates can be analyzed which are so low in total protein that chemical analysis is inaccurate and the ordinary fractionation into albumin and globulin impossible. Previous studies (10) with edematous dogs indicated that it was justifiable to compare the albumin:globulin ratio of a transudate with the ratio of the serum obtained simultaneously.

Albumin and globulin were isolated from pooled human sera of normal individuals, and antisera 


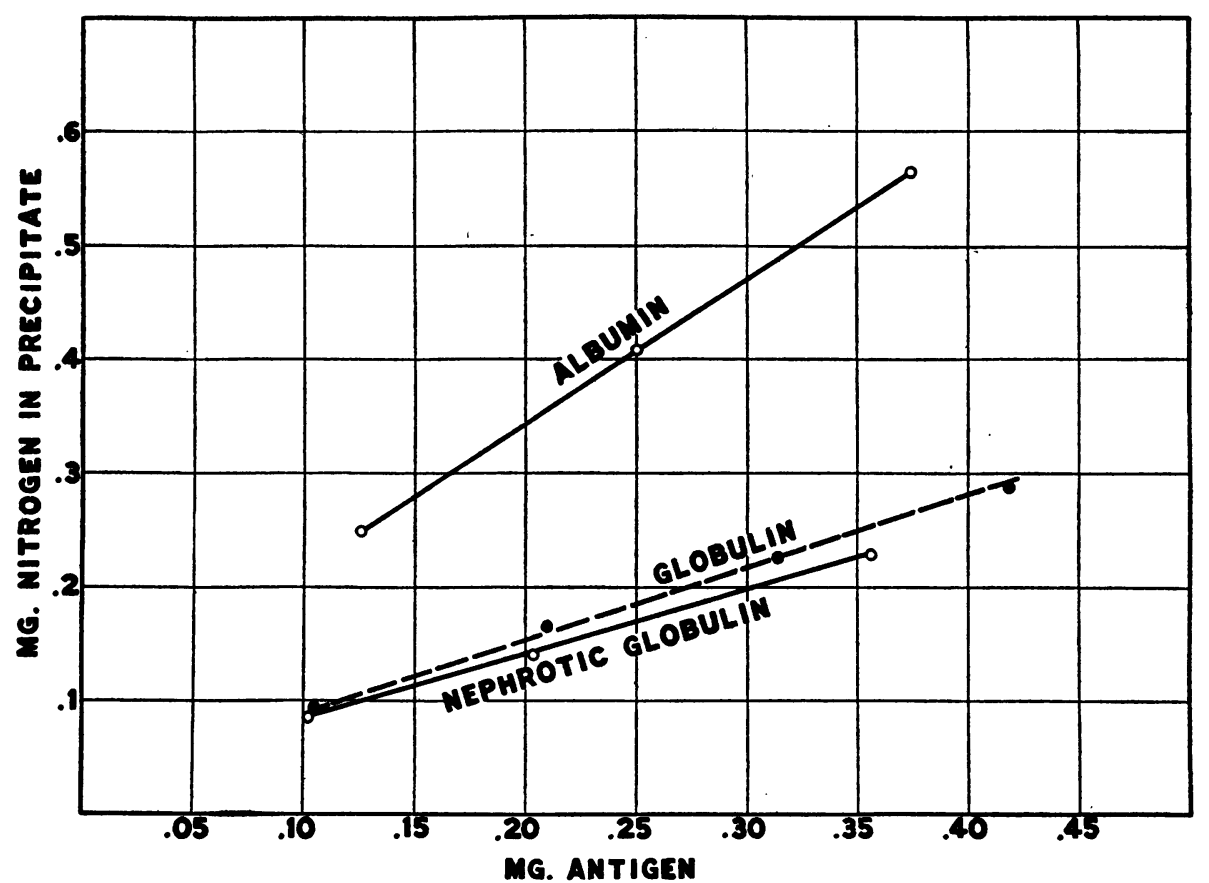

Fig. 1. Standardization Curves of the Antisera.

were developed in rabbits with each fraction in a manner previously described (10). Each antiserum was standardized against pooled normal human sera, yielding the standardization curves shown in Figure 1. Serum, urine, and transudates obtained from patients on the same day were analyzed both by Howe's method (11) and by the precipitin method (10). The data obtained on a few patients with edema from causes other than nephrosis or nephritis are presented in Table I. Agreement between the two methods is close for serum as well as for transudates, and in Baby C. analysis of the serum by the precipitin method gave reliable results both during the edematous stage and after edema had disappeared. These data, summarized in Table I, corroborate studies carried out previously on the sera of normal and edematous dogs (10), and further demonstrate the close correlation between results obtained by the two methods when edema was present or when it was absent.

The first patient with nephrosis available for study was D. L., a 20-months-old girl, admitted to Babies Hospital on May 4, 1934, during her initial attack of edema. Serum, urine, and edema fluid were obtained shortly after admission and analyzed by Howe's method. When the serum was analyzed by the precipitin method, it was apparent at once from the small amount of precipitate thrown down that neither the albumin nor the globulin was reacting with the respective antiserum as completely as normal serum proteins react. Analysis of the precipitates for total nitrogen confirmed this observation. The amount of albumin estimated by the precipitin method was found to be only thirteen per cent of the value obtained by Howe's method; the value for globulin was approximately half that obtained on salting out the proteins. Another sample of serum obtained a few days later yielded similar results. Since the cholesterol content of the nephrotic serum was high, it seemed possible that the failure to obtain complete reaction between the antigen and the antiserum might be due to the lipoid. Attempts to clear the serum with ether, chloroform, or acetone resulted in no change in the serological reaction. Ethylene chloride proved to be a more satisfactory reagent for removing cholesterol, and after extraction the serum was clear, with unaltered total protein and a low cholesterol value. There was no change, however, in the reaction with the antisera. Therefore the inability to precipitate the nephrotic proteins could not be ascribed to the high cholesterol content. It was 
TABLE I

Analyses of sera and transudates from patients with edema from other causes than nephritis or nephrosis. Comparison of Howe's method and the precipitin method

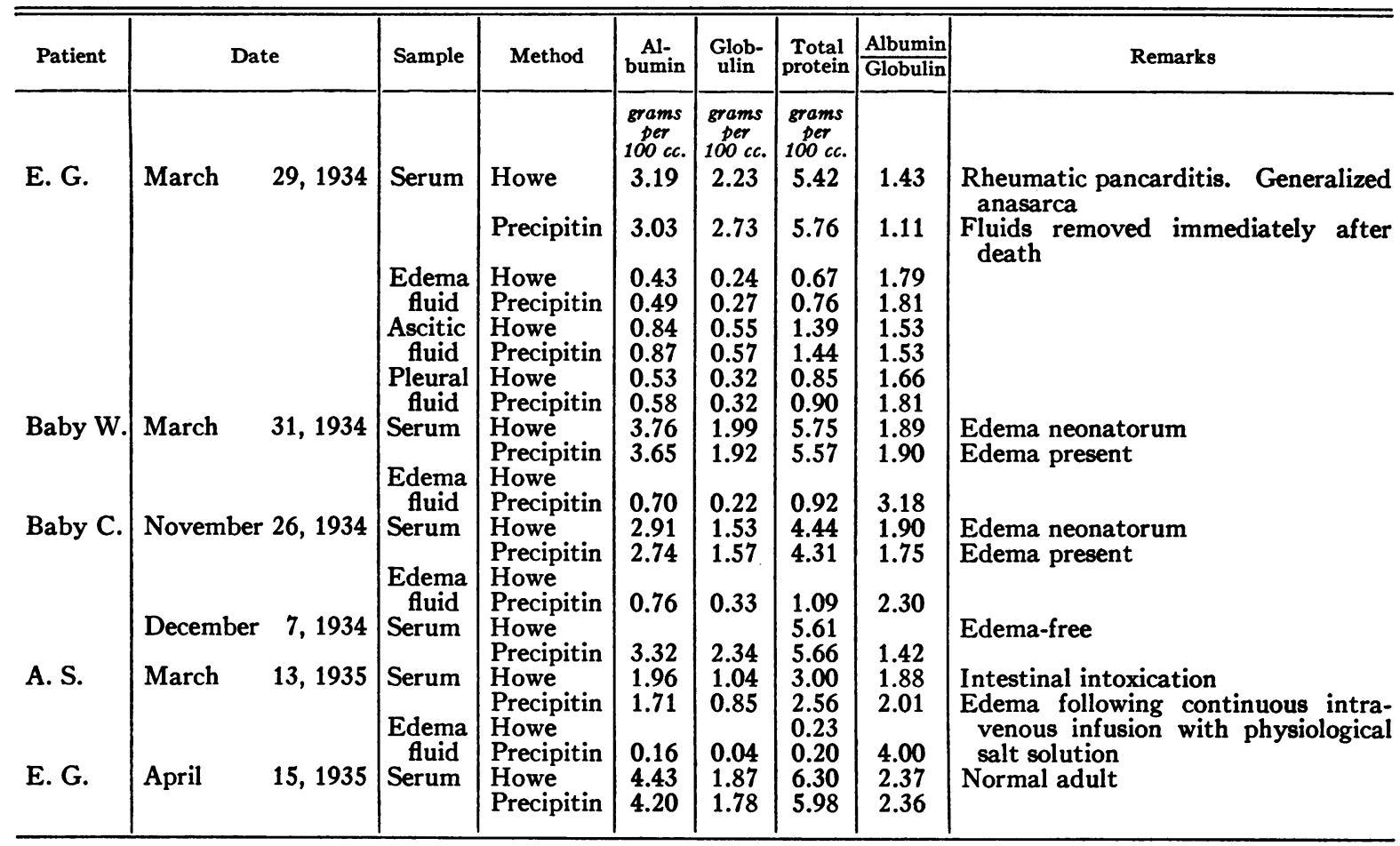

TABLE II

Analyses of serum from a case of nephrosis (D. L., 20 months of age).

Comparison of Howe's method and the precipitin method

\begin{tabular}{|c|c|c|c|c|c|c|c|c|}
\hline & Date & $\begin{array}{c}\text { Days } \\
\text { follow- } \\
\text { ing } \\
\text { admis- } \\
\text { sion }\end{array}$ & Method & $\begin{array}{c}\text { Al- } \\
\text { bumin }\end{array}$ & $\begin{array}{l}\text { Glob- } \\
\text { ulin }\end{array}$ & $\begin{array}{c}\text { Total } \\
\text { protein }\end{array}$ & $\frac{\text { Albumin }}{\text { Globulin }}$ & Remarks \\
\hline & & & & $\begin{array}{l}\text { grams } \\
\text { per } \\
100 \mathrm{cc} .\end{array}$ & $\begin{array}{l}\text { grams } \\
\text { per } \\
100 \mathrm{cc} .\end{array}$ & $\begin{array}{l}\text { grams } \\
\text { per } \\
100 \mathrm{cc} .\end{array}$ & & \\
\hline & $5,1934 \ldots \ldots \ldots \ldots$ & 1 & $\begin{array}{l}\text { Howe } \\
\text { Precipitin }\end{array}$ & $\begin{array}{l}1.47 \\
0.10\end{array}$ & 2.79 & 4.26 & 0.53 & Generalized anasarca \\
\hline May & $10,1934 \ldots \ldots \ldots \ldots$ & 6 & Howe. & & & & & Generalized anasarca \\
\hline May & 21,1934 & 17 & $\begin{array}{l}\text { Precipitin } \\
\text { Howe }\end{array}$ & $\begin{array}{l}0.07 \\
1.39\end{array}$ & $\begin{array}{l}1.45 \\
2.84\end{array}$ & $\begin{array}{l}1.52 \\
4.23\end{array}$ & $\begin{array}{l}0.05 \\
0.49\end{array}$ & Diuresis in progress \\
\hline May & 26,1934 . & 22 & $\begin{array}{l}\text { Precipitin } \\
\text { Howe }\end{array}$ & $\begin{array}{l}0.34 \\
1.99\end{array}$ & $\begin{array}{l}2.22 \\
2.74\end{array}$ & $\begin{array}{l}2.56 \\
4.73\end{array}$ & $\begin{array}{l}0.15 \\
0.73\end{array}$ & $\begin{array}{l}\text { Edema and ascites still present } \\
\text { Diuresis in progress }\end{array}$ \\
\hline June & 7, 1934 & 34 & $\begin{array}{l}\text { Precipitin } \\
\text { Howe }\end{array}$ & $\begin{array}{l}0.43 \\
2.24\end{array}$ & 2.80 & 3.23 & 0.15 & Edema and ascites still present \\
\hline$\pi$ & & & Precipitin & 1.50 & 3.04 & 4.54 & 0.49 & Edema-ıree \\
\hline June & 20,1934 & 47 & Howe & 2.75 & 3.15 & 5.90 & 0.87 & Edema-free \\
\hline July & 11,1934 . & 68 & Howe & 2.94 & 3.38 & 6.32 & 0.87 & Discharged home June 28,1934 \\
\hline August & 9,1934 & 97 & $\begin{array}{l}\text { Precipitin } \\
\text { Howe }\end{array}$ & $\begin{array}{l}2.18 \\
3.69\end{array}$ & $\begin{array}{l}3.20 \\
2.76\end{array}$ & $\begin{array}{l}5.38 \\
6.45\end{array}$ & $\begin{array}{l}0.68 \\
1.34\end{array}$ & $\begin{array}{l}\text { Edema-free } \\
\text { Edema-free }\end{array}$ \\
\hline Octoher & & & Precipitin & 3.35 & 3.24 & 6.59 & 1.03 & \\
\hline October & 24,1934 . & 173 & $\begin{array}{l}\text { Howe } \\
\text { Precinitin }\end{array}$ & $\begin{array}{l}3.97 \\
3.82\end{array}$ & 2.28 & $\begin{array}{l}6.25 \\
5.93\end{array}$ & $\begin{array}{l}1.74 \\
1.81\end{array}$ & Edema-free \\
\hline December & 5,1934 . & 215 & Howe. & 4.20 & 2.10 & 6.30 & 2.0 & Edema-free \\
\hline June & 26,1935 & 418 & $\begin{array}{l}\text { Hrecipitin } \\
\text { Howe } \\
\text { Precipitin }\end{array}$ & $\begin{array}{l}4.01 \\
3.96 \\
3.73\end{array}$ & $\begin{array}{l}1.99 \\
2.05 \\
1.71\end{array}$ & $\begin{array}{l}0.00 \\
6.01 \\
5.44\end{array}$ & $\begin{array}{l}2.02 \\
1.93 \\
2.18\end{array}$ & $\begin{array}{l}\text { Occasional slight puffiness of eye- } \\
\text { lids in the morning }\end{array}$ \\
\hline
\end{tabular}




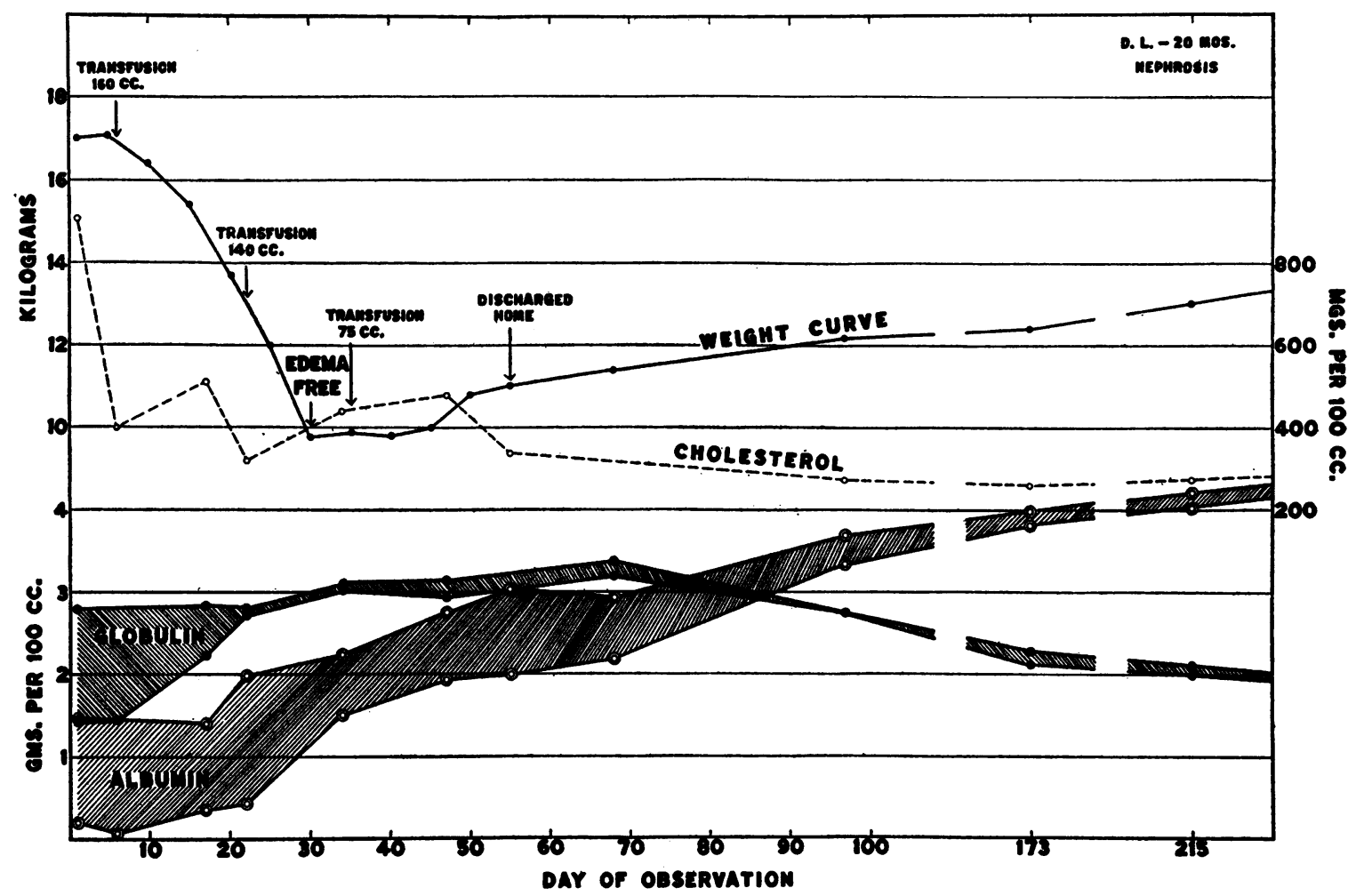

Fig. 2. Clinical Course in Patient D. L.

The hatched areas show the deficits of the serum albumin and globulin determined by the precipitin method. The upper points of both hatched areas represent the values obtained by Howe's method, the lower points those obtained by the precipitin method.

further determined that addition of the nephrotic serum to normal serum caused no interference with the predicted precipitation of the normal proteins. Subsequent analyses of the serum of this patient are presented in Table II and the clinical course is indicated in Figure 2. Following diuresis and the disappearance of the edema, the globulin fraction rapidly regained its ability to precipitate the antiserum completely. The albumin fraction recovered its normal serological response more slowly over a period of several months long after the patient had been discharged from the hospital. Transfusions had little or no effect on the determination by the precipitin method provided the serum for analysis was withdrawn several days following the transfusion.

It was possible to confirm the above findings by studies on several other patients with nephrosis. Similar results were obtained on an older child, J. F., a boy five years of age who was admitted to the Babies Hospital on June 21, 1934, with generalized anasarca during his third attack of nephrotic edema. The data are presented in Table III, and in Figure 3 the clinical course is outlined. One or more observations were made on six other patients with nephrosis, and the data are summarized in Table IV. It will be noted that the serum of all of these patients showed the same phenomenon of incomplete precipitation by specific antisera. During convalescence in one patient the serological behavior of both fractions became normal; in one other patient, in whom prolonged study was possible, both albumin and globulin changed in the direction of a return to the normal serological response.

Several patients with acute glomerular nephritis were then studied to determine whether the serum proteins in this disease show the same incomplete precipitation with the antisera. Most of the patients were edematous, and in two of them, C. P. and N. V., the albumin: globulin ratio was inverted, although the total protein was higher than 
TABLE III

Analyses of serum from a case of nephrosis ( $J . F, 5$ years of age).

Comparison of Howe's method and the precipitin method

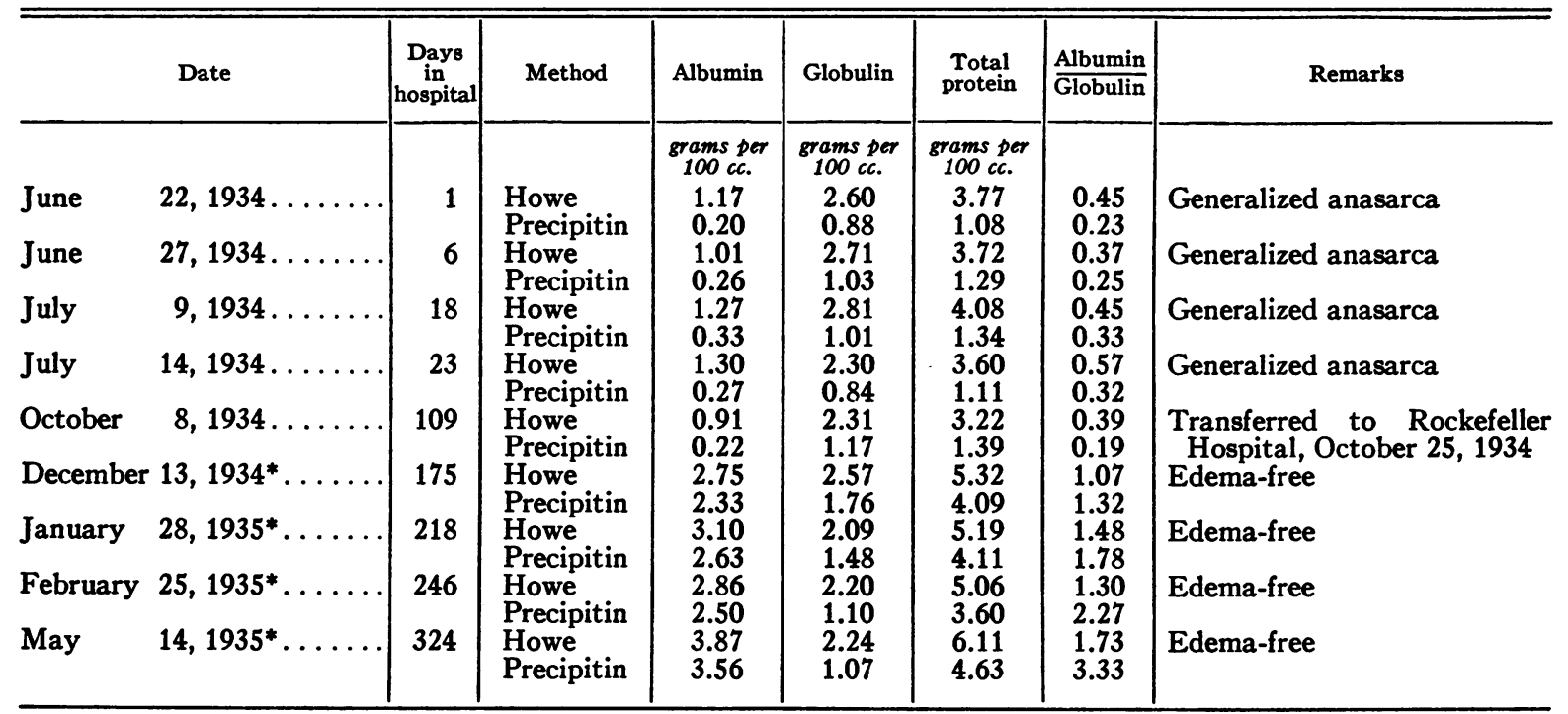

* These sera were obtained through the kindness of Dr. L. Farr of Rockefeller Hospital.

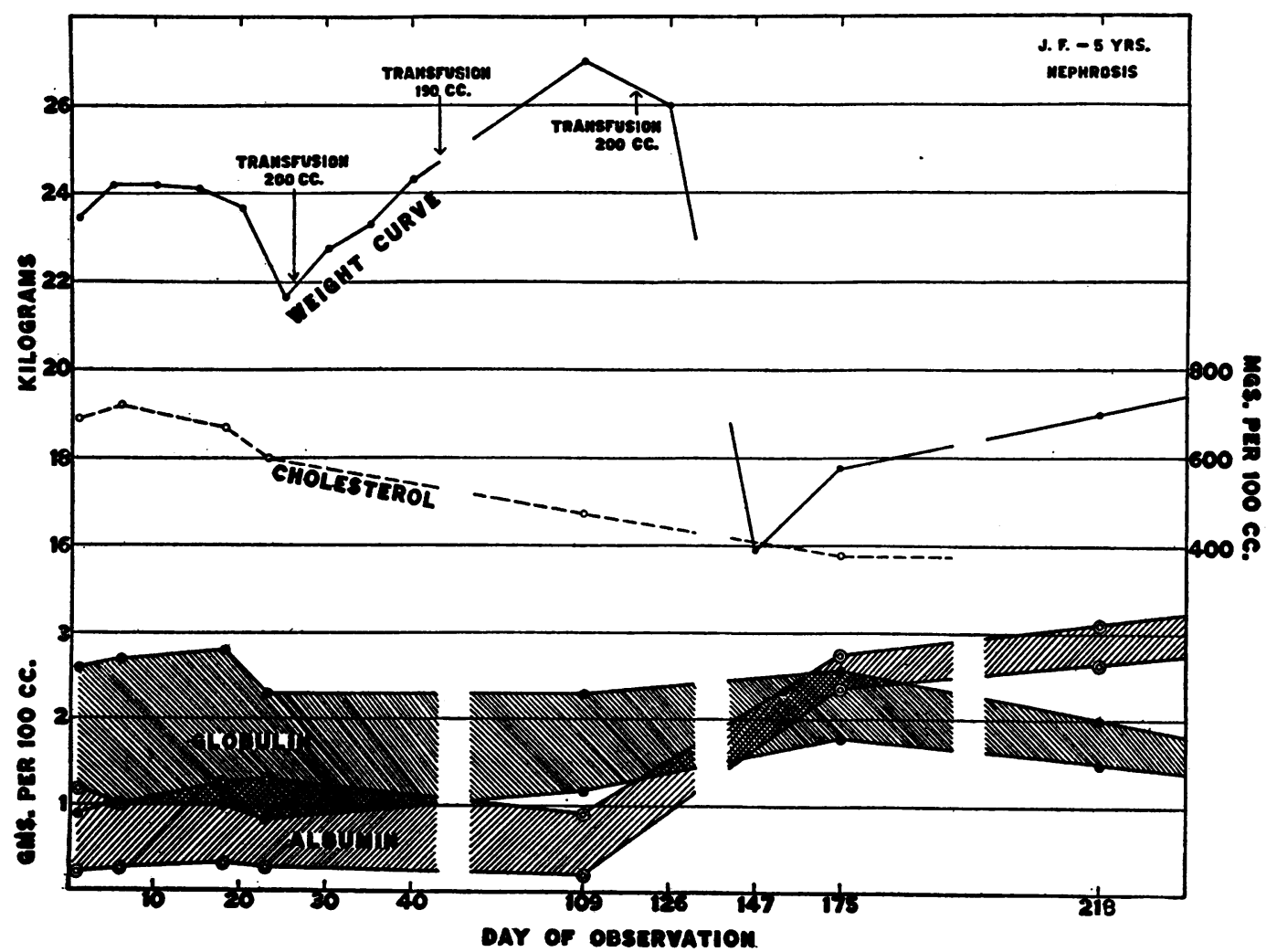

Fig. 3. Clinical Course in Patient J. F.

The hatched areas show the deficits of the serum albumin and globulin determined by the precipitin method. The upper points of both hatched areas represent the values obtained by Howe's method, the lower points those obtained by the precipitin method. 
TABLE IV

Analyses of sera from cases of nephritis and nephrosis. Comparison of Howe's method and the precipitin method

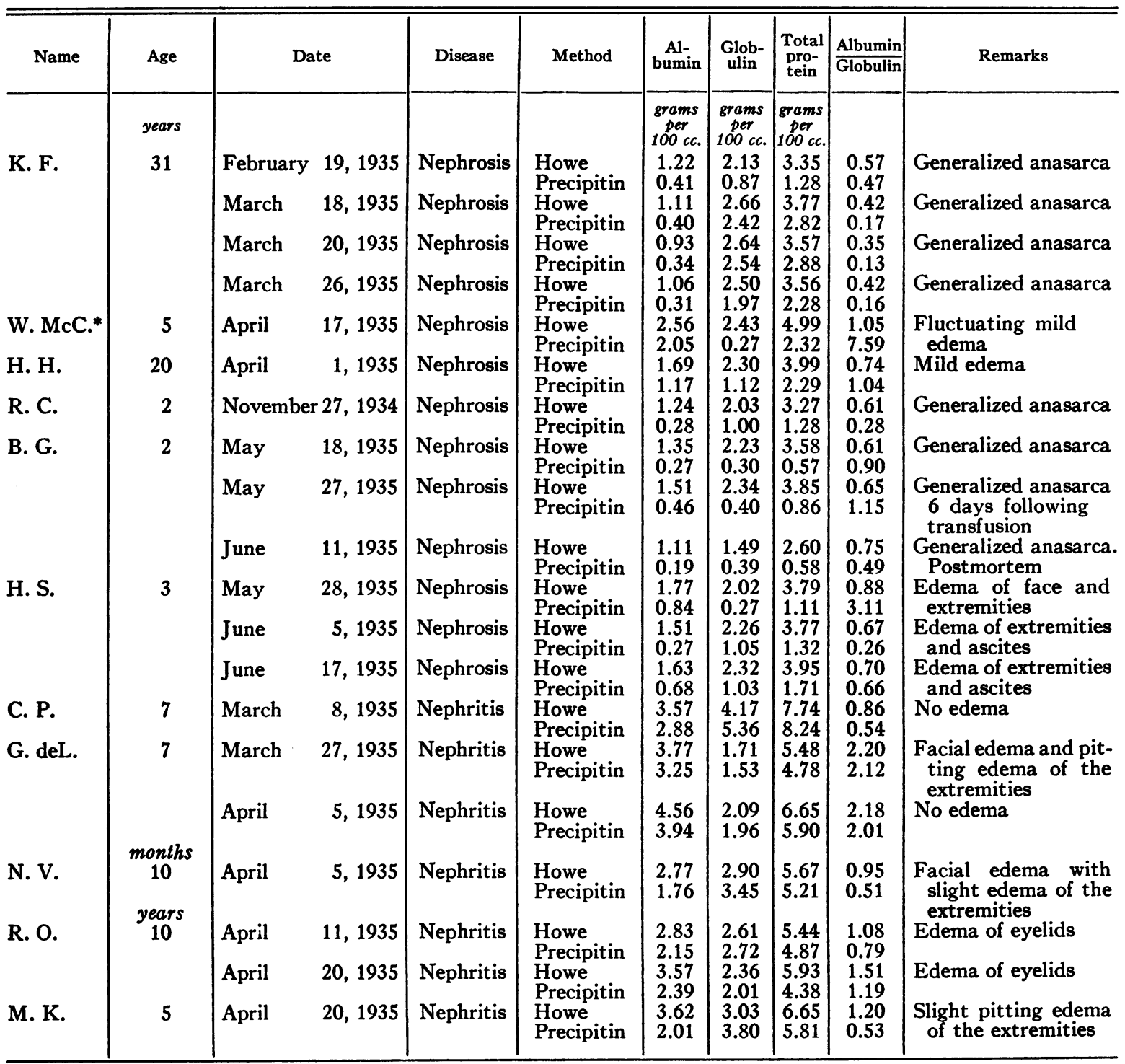

* This serum was obtained through the kindness of Dr. H. Koenig of New York Hospital.

in the nephrotic group. From the data included in Table IV it is evident that marked deficits in the amount of albumin and globulin precipitated did not occur.

Since both of the antigens used to prepare the antisera were composed of various subfractions, which are antigenically distinct and which vary in their ability to evoke antibody formation, it was expected that estimation by the precipitin method would fail where wide deviations from the normal distribution of these subfractions occurred. Examination of the data, summarized in Table V, shows that in the serum of a patient with kalaazar the high euglobulin content resulted in a high value for globulin by the precipitin method. Two patients with nephritis, M. K. and C. P., with high euglobulin fractions confirm this finding. However, deviation from the normal distribution of globulin subfractions does not explain the deficit in precipitation found in nephrotic 
SERUM PROTEINS IN NEPHROSIS

TABLE V

Relationship of the various globulin fractions to the amount of globulin determined by the precipitin method

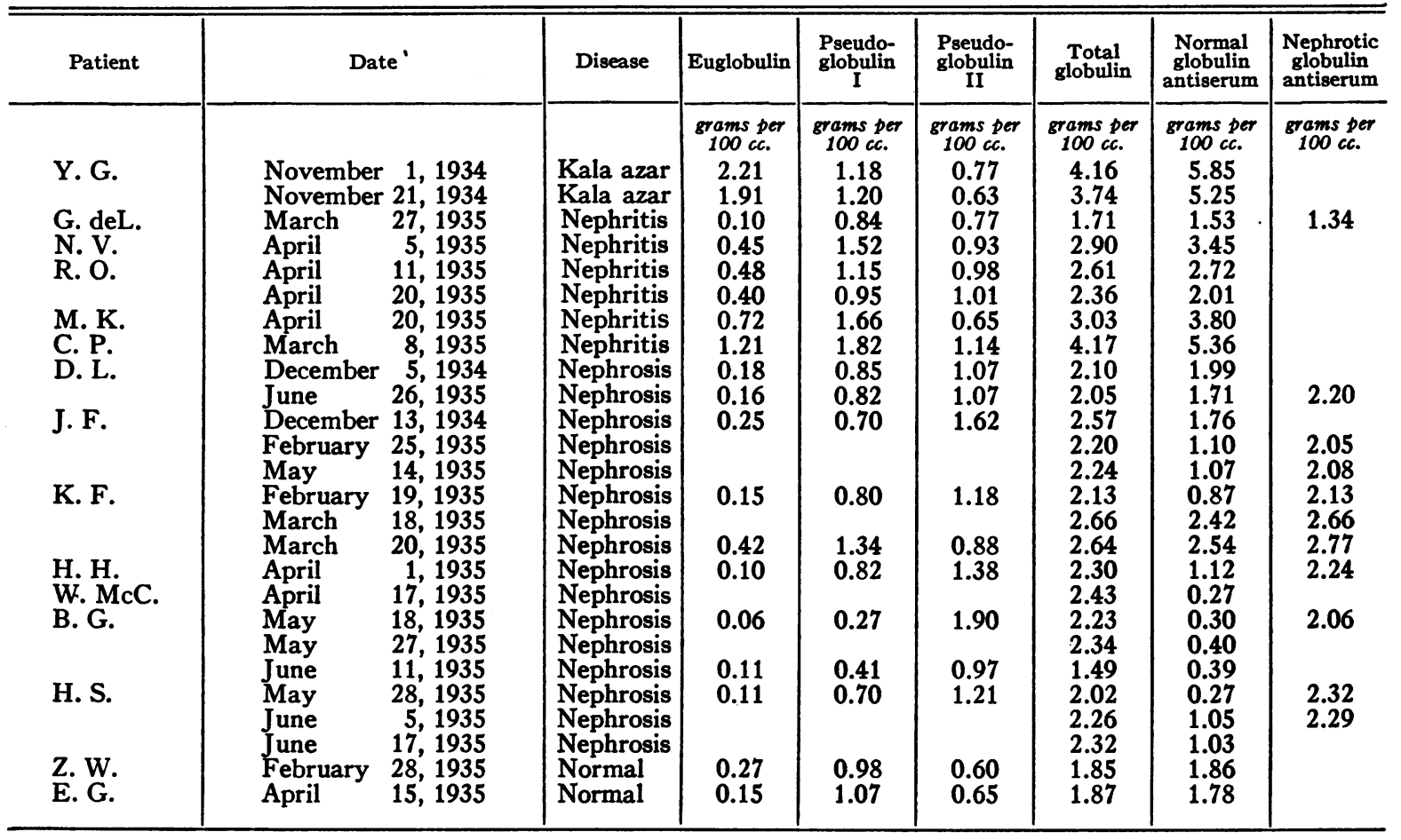

sera. A comparison of the analysis of the serum from a patient who had recovered from nephrosis, D. L.-December 5, 1934, with that from a patient in the edematous stage, K. F.-February 19, 1935 , reveals practically the same subfractions in each, and yet the one, D. L., precipitated completely while the other, K. F., showed a large deficit.

It seemed important to determine whether the nephrotic serum proteins might serve as antigens for the production of antisera with which the serum and transudates of nephrotic patients could be analyzed by the quantitative precipitin method. Because of the small quantity of serum available, only the globulin fraction was obtained in sufficient quantity for the immunization of a few rabbits. The nephrotic serum was cleared with ethylene chloride to remove most of the lipoid, and the globulin was precipitated at half saturation with ammonium sulphate as usual. Rabbits were immunized with the nephrotic globulin and the antiserum produced was standardized against the original nephrotic globulin antigen; the curve is included in Figure 1. The results of analyses of sera from nephrotic patients with both the normal globulin antiserum and the nephrotic globulin antiserum are shown in Table V. The globulin could be correctly estimated by the precipitin method whenever the nephrotic globulin antiserum was used, although the usual deficit was recorded in all but one case when the normal globulin antiserum was used. In this patient, $K$. F., the nephrotic globulin antiserum was effective at all times; however, the normal globulin antiserum failed to precipitate the globulin on February 19, 1935, and was effective a month later after a radical change in the globulin subfractions had occurred. Unfortunately, the lack of sufficient nephrotic globulin antiserum precluded further studies for the time being.

Studies of the urine from most of the patients were carried out. Protein was precipitated with trichloracetic acid, the precipitate was analyzed for nitrogen, and the customary factor 6.25 was employed to calculate the total protein. Precipitin analyses were set up at the usual dilutions. In nephrosis when edema was present, it was possible by means of the precipitin method to re- 
cover consistently a larger fraction of the urinary proteins than of the serum proteins. A few characteristic analyses are presented in Table VI

TABLE VI

Analyses of sera and urine from edematous nephrotic patients by chemical methods and the precipitin method

\begin{tabular}{|c|c|c|c|c|c|c|}
\hline Name & Sample & Method & $\begin{array}{c}\text { Al- } \\
\text { bumin }\end{array}$ & $\begin{array}{l}\text { Glob- } \\
\text { ulin }\end{array}$ & $\begin{array}{l}\text { Total } \\
\text { protein }\end{array}$ & $\begin{array}{c}\text { Total } \\
\text { protein } \\
\text { recovered } \\
\text { by } \\
\text { precipitin } \\
\text { method }\end{array}$ \\
\hline \multirow{2}{*}{ D. L. } & Urine & \multirow{2}{*}{$\begin{array}{l}\text { Chemical } \\
\text { Precipitin } \\
\text { Howe }\end{array}$} & $\begin{array}{c}\text { grams } \\
\text { per } \\
100 \mathrm{cc} .\end{array}$ & $\begin{array}{l}\text { grams } \\
\text { per } \\
100 \mathrm{cc} .\end{array}$ & $\begin{array}{c}\text { grams } \\
\text { per } \\
100 \mathrm{cc} .\end{array}$ & per cent \\
\hline & Serum & & $\begin{array}{l}1.04 \\
1.47 \\
0.19\end{array}$ & $\begin{array}{l}0.03 \\
2.79 \\
1.43\end{array}$ & $\begin{array}{l}1.07 \\
4.26 \\
1.62\end{array}$ & $\begin{array}{l}60.4 \\
38.0\end{array}$ \\
\hline B. G. & Urine & Chemical & & & 0.82 & 30.0 \\
\hline & Serum & & $\begin{array}{l}0.37 \\
1.35\end{array}$ & $\begin{array}{c}\text { trace } \\
2.23\end{array}$ & $\begin{array}{l}0.37 \\
3.58\end{array}$ & 45.1 \\
\hline K. F. & Urine & & 0.27 & 0.30 & $\begin{array}{l}0.57 \\
2.14\end{array}$ & 15.9 \\
\hline & Serum & $\begin{array}{l}\text { Precipitin } \\
\text { Howe }\end{array}$ & $\begin{array}{l}1.17 \\
1.22\end{array}$ & $\begin{array}{l}0.39 \\
2.13\end{array}$ & $\begin{array}{l}1.56 \\
3.35\end{array}$ & 72.9 \\
\hline . F. & Urine & $\begin{array}{l}\text { Precipitin } \\
\text { Chemical }\end{array}$ & 0.41 & 0.87 & $\begin{array}{l}1.28 \\
1.55\end{array}$ & 38.2 \\
\hline & Serum & $\begin{array}{l}\text { Precipitin } \\
\text { Howe }\end{array}$ & $\begin{array}{l}0.85 \\
1.30\end{array}$ & $\begin{array}{l}0.18 \\
2.30\end{array}$ & $\begin{array}{l}1.03 \\
3.60\end{array}$ & 66.4 \\
\hline & & Precipitin & 0.27 & 0.84 & 1.11 & 30.8 \\
\hline
\end{tabular}

which demonstrate this fact. The findings suggest that the protein which is excreted during the edematous stage is not the serum protein which shows serological changes.

\section{SUMMARY}

1. Data obtained by the quantitative precipitin method indicate that during the edematous stage of nephrosis the serum proteins differ immunologically from normal serum proteins, in that both albumin and globulin fail to precipitate completely with antisera developed against normal serum albumin and normal serum globulin. During convalescence after edema has disappeared, both albumin and globulin gradually recover their normal serological behavior.

2. The serum proteins of patients with acute hemorrhagic nephritis do not show similar changes.
3. Neither the high cholesterol content of nephrotic serum nor the abnormal distribution of the subfractions, in the case of the globulin, is the cause of the incomplete precipitation.

4. Globulin isolated from nephrotic serum is capable of stimulating antibody response in rabbits, and the antiserum formed is not identical with that formed against globulin obtained from normal serum.

\section{BIBLIOGRAPHY}

1. Leiter, L., Nephrosis. Medicine, 1931, 10, 135.

2. Widdowson, E. M., A comparative investigation of urine- and serum-proteins in nephritis. Biochem. J., 1933, 27, 1321.

3. Hewitt, L. F., Optical rotatory power and dispersion of proteins. Biochem. J., 1927, 21, 216.

Identity of urinary albumin. Biochem. J., 1927, 21, 1109.

Urine proteins in nephrosis, pregnancy, and myelomatosis. Lancet, 1929, 1, 66.

4. Cavett, J. W., and Gibson, R. B., A comparison of the racemization curves for urinary, edema fluid, and blood plasma proteins. J. Clin. Invest., 1931, $10,857$.

5. Mertens, V. E., Ein biologischer Beweis für die Herkunft des Albumen im Nephritisharn aus dem Blute. Deutsche med. Wchnschr., 1901, 27, 161.

6. Erben, F., Studien über nephritis. Ztschr. f. klin. Med., 1903, 50, 441.

7. Müller, F., Bezeichnung und Begriffsbestimmung auf dem Gebiet der Nierenkrankheiten. Veröffentl. a. d. Geb. d. Militär-Sanitätswesens, 1917, 65, 21.

8. a. Thomas, W. A., Schlegel, K. W., and Andrews, E., Urinary proteins not originating in blood. Arch. Int. Med., 1928, 41, 445.

b. Andrews, E., Thomas, W. A., and Welker, W. F., Albuminuria in the mechanism of detoxification. Arch. Int. Med., 1929, 43, 139.

c. Welker, W. H., Andrews, E., and Thomas, W., Identity of the urinary proteins of nephritis. J. A. M. A., 1928, 91, 1514.

$d$. Thomas, W. A., Source and rôle of urinary protein in nephritis. J. A. M. A., 1931, 97, 1055.

9. Cowie, D. M., and Magee, M. C., Organ specificity of human tissue in relation to proteinuria. Am. J. Dis. Child. (Abstract), 1935, 49, 1388.

10. Goettsch, E., and Kendall, F. E., Analysis of albumin and globulin in biological fluids by the quantitative precipitin method. J. Biol. Chem., 1935, 109, 221.

11. Howe, P. E., The determination of proteins in blood -a micro method. J. Biol. Chem., 1921, 49, 109. 